\title{
Regulation of Recovery Region Around Mine Based on Law Number 3 of 2020 Concerning Amendments to Law Number 4 of 2009 Concerning Mineral and Coal Mining
}

\author{
Hudriyah Mundzir $^{1 *} \quad$ Khrisna Hadiwinata $^{1} \quad$ Shohib Muslim ${ }^{2}$ \\ 1.Electrical Engineering Major, Politeknik Negeri Malang, Indonesia \\ 2.Majoring in Information Technology, Politeknik Negeri Malang, Indonesia \\ Jl. Soekarno Hatta 9 Malang 65141
}

\begin{abstract}
Law Number 4 of 2009 concerning Mineral and Coal Mining, hereinafter referred to as the Minerba Law, is a new legal construct that replaces Law Number 11 of 1967 concerning Basic Provisions of Mining whose replacement is due to Law Number 11 of 1967 concerning Basic Mining Provisions does not explicitly state the prevention and restoration arrangements for the area around the mine. There is no explicit mention of prevention and recovery arrangements for the area around the mine, causing various impacts on communities around the mine and the environment. So that it makes the author interested in researching about "Regional Government Authorities related to Prevention and Recovery Regulations for Areas around Mining based on Law Number 4 of 2009 concerning Mineral and Coal Mining".
\end{abstract}

Keywords: area around the mine, prevention and recovery, mining and coal.

DOI: $10.7176 / \mathrm{JLPG} / 104-06$

Publication date: December $31^{\text {st }} 2020$

\section{Introduction}

Article 33 subsection 3 Constitution of Republic of Indonesia 1945, everything regarding natural resources lies within the territory of Republic of Indonesia was governed, managed and distributed by the state with its management institution for people welfare. To obtain this objective, the government was authorized to made new policies that could affect and improve people welfare, including by cooperating with the third party.

One of the government's policy concerning electricity was providing rural electricity and free electricity installation through Directorate General of Electric Power under Energy and Mineral Resources Ministry to conduct Rural Electricity and Free Electricity Installation in all rural and hinterland parts in Indonesia. The government along with PLN and its co-institution was implementing this program. This policy would be given toward each region to conduct assessment for poor regions through Governor Decree and grant decree from Directorate General of Electric Power under Energy and Mineral Resource Ministry. Local government was free to work with private party in implementing this policy. This cooperation was cooperation between the government represented by Pejabat Pembuat Komitmen Listrik according to Decision of Directorate General of Electric Power under Energy and Mineral Resources Ministry with the third party or private party.

In this cooperation, the government was using contract medium as the bridge for both sides. This contract was different than any general contract. Contract that was run by the government or at least whereas the government was involved was not arranged in the constitutional regulation. This policy exists because the government was authorized to conduct the act of government as an effort to create people's welfare. Many would call it as government contract and some would know it as public contract. The point is the participation of the government as one of the party in this contractual activity. Such contract was not only comply the private law but also comply to public law, therefore policies under the contract of rural electricity and free electricity installation contain public regulations which affects it.

The contract of rural electricity and free electricity installation was a formal and standard contract, in which it was made exclusively by the government without any agreement, some of its clause usually tend to weighed against the private party but still cannot be said as not proportional without further testing or analysis. The main problem occurs during compensation discussion if the government would breach the contract to the private party. Civil law has arranged proportional compensation for such matters but when the government was involved in the contract, can this compensation arrangement still valid according to the norm under civil law? When we were talking about compensation, the government cannot move freely or compensate with any fund existed because there was state treasury involved in this which has the duty to regulate state finance including the loss.

In reality, contract clauses which comply the presidential regulation cannot clearly defined and could create a perception that the government can conduct an exclusive act or decision in order to avoid paying compensation or delay compensation payment under the statement of careful management of state money. The objective of a contract was to give assurance and fairness for all parties involved, because contract created from the interests of all parties and protected by the law. 


\section{Objectives}

To analyze compensation in the contract of Rural Electricity and Free Electricity Installation program and as knowledge insight for scholars and all parties involved in provisional contracts.

\section{Study Method}

Study method used was normative research with constitutional and conceptual approaches. Legal analysis was done in prescriptive manner with deductive-inductive reasoning toward legal regulation using legal interpretation.

\section{Study Results}

Philosophical aspect, philosophical aspect concerning why contract was always become an interesting topic to discuss was because contract was experiencing rapid development due to business world central after the globalization current. Contract was no longer private in nuance but it was developed in many aspects. Contract as the legal base for each cooperation activities was expected to provide legal protection, legal certainty and legal protection for each individual/institution involved in the cooperation. Contract was made from agreement results or interests of each individual/institution involved. Philosophical view was divided into 3 parts such as ontology, epistemology and axiology.

Ontology aspect, contract as the legal base for all the involved parties should be arranged in careful manner including concerning compensation because it was part of the contractual agreement. Epistemology aspect, compensation should be fair and regulated under a clear norm, and the collateral should be in accordance, juridically, with the purpose of a contract.

Axiology aspect, contract should be balanced regulated and refers to constitutional regulation in order to obtain fairness.

Results of this study were as follows:

\subsection{Government contract related with provisional activities}

Definition of government contract under constitutional regulation in Indonesia was not explicitly regulated, however definition of government contract can be found in Malaysia. Government contract was stated in Act 120 of Government Contracts Act 1949:

"All contracts made in Malaysia on behalf of the Government shall, if reduced to writing, be made in the name of the Government of Malaysia and may be signed by a Minister or by any public officer duly authorized in writing by a Minister, either specially in any particular case, or generally for all contracts below a certain value in his department or otherwise as may be specified in the authorization." (Government Contract Act, 1949) ${ }^{1}$

While in Indonesia, government contract was made from contractual activities of the government in working its capacity as the subject in private law domain. This activity would include an act or deed conduct by state administration while working its government duty. ${ }^{2}$ Kontjoro Purbopranoto suggests that government act is all authorized acts of government tools to conduct its duty/objective by using certain/particular authority. ${ }^{3}$ This legal act would furthermore divide into two parts, private legal act and public legal act.

The act of the government was represented by its institution or its official officers. In their activities, officers or institutions act through two roles, such as:

1. As the public actor that run the public authority (openbaar gezag) and manifested into authority's quality such as state administrative institutions and various posts with authority to use public power.

2. As the civil actor that conduct various civil acts (privaatrechtelijke handeling), such as transactional contract, rental contract, contracting out, and others manifested into authority's quality (legal person, rechtpersoon). ${ }^{4}$

Contractual law in managing government affairs was commonly known as contractualization, in which there was a mix between private and public element within the contractual relationship. ${ }^{5}$ One of the state's policies was to cooperate with the third party for development or general service provisions (Indiharto, 2002). The cooperation was based under public law. Philipus M. Hadjon was citing Kranenburg suggestion which state that "agreement based on public law was the agreement to conduct the governmental affairs and that it was regulated under public law". ${ }^{6}$ Contract whereas the government act as one of the party was known, in several literatures, as government contract that was not yet explicitly described about its differences (related to other type of contract) and the government's position within it. Government contract emerge from general interests for people's welfare. This welfare should be fulfill by the government as one of the state's duty, as mentioned in the Constitution of Republic

\footnotetext{
${ }^{1}$ Government Contract Act 1949, Artikel 2, Act 120-, pg. 1

${ }^{2}$ Philipus M Hadjon, Pengertian-pengertian Dasar tentang Tindak Pemerintahan,Jumali, Surabaya, 1985, pg. 1

${ }_{3}^{3}$ Kuntjoro Purbopranoto, Beberapa Catatan Hukum Tata Pemerintahan dan Peradilan Administrasi Negara, Alumni Bandung, 1987, pg. 2

${ }^{4}$ Philipus M.Hadjon,dkk, Pengantar Hukum Administrasi Indonesia, Gajdjah Mada University Press, Yogyakarta, 2011, pg. 165

${ }^{5}$ Sogar Simamora,Hukum Kontrak, Laksbang Justitia, Surabaya, Surabaya, 2013, pg. 41

${ }^{6}$ Phillipus M Hadjon, Pengertian Dasar Tindakan Pemerintahan, Jurnali, Surabaya, 1985, pg. 42
} 
of Indonesia 1945. Under government's authority, several policies were created to obtain this goal. One of these policies was concerning rural electricity and free electricity installation under cooperation with third party through a contract. Government's authority for civil law particularly in contractual affairs was not regulated and mostly emerged from government's authority.

In the practice of implementation, the government has tied themselves with the third party in a contract agreement. Type of government contract consists of:

a) Goods/service provisional contract

b) Non goods/service provisional contract

For the contract of Rural Electricity and Free Electricity Installation, it was one of the provisional contracts and regulated under Presidential regulation No 54 of 2010 jo. Presidential regulation No 35 of 2011 jo. Presidential regulation No 70 of 2012 jo. Presidential regulation No 172 of 2014 jo. Presidential regulation No 4 of 2015.

\subsection{Breach of Contract in Rural Electricity and Free Electricity Installation Agreement}

Provision in Article 1234 Civil law code suggested that "every involvement was to give something, to do something and to not do something." Contract for government's goods/service provision was an agreement. An agreement was an event whereas one promise to do something, and therefore, relationship between involvement and agreement was that agreement published the involvement. Agreement was the source of involvement, as stated in Article 1234 of Civil law code that "each involvement occurs due to approval and constitution". Involvement was also called approval, according to R. Subekti, "because it was narrower and refers to the written agreement or approval". Contract that was made legally has the valid legal power, has the value and has the binding power for those involved in it. This is the consensualism principle exists within the contract and includes a legal basis suggested in Article 1338 subsection (1) of Civil law code that every legitimate agreement acts as the constitution for the parties involved.

Whether the implementation of goods/service provisional contract was done accordingly should be viewed during the contract implementation. During this implementation stage, responsibility lies on the hand of government's goods/service provider. Any disadvantages or ill-time implementation was prone to make the provider deemed to breach the contract as regulated in article 1339 civil law code which suggest that the agreement was not only binding toward what was mention explicitly but also binding toward anything compulsory, according to trait, worthiness, habit and constitution. It was also described explicitly in Article 1235 of Civil law code that the agreement to give something would covers the duty to give and maintain the safety of the goods/service until it is delivered. When goods/service provider did not act according to the agreed contract or has breach it and thus being late from the scheduled time or did not act according to the contract, it can be said that the provider has conduct breach of contract (default). Breach of contract means that they did not conduct the provisions stated in the contract as said in article 1234 of Civil law code that each involvement was to give something, to do something or not to do something. The government was breaching the contract if they were negligent in this goods/service provision contract and thus were late than the predetermined schedule or inappropriately implementing the terms and service within the contract.

In Article 118 of Government Regulation No 54 of 2010, it determines that action by goods/service provider was eligible to sanction if they cannot finish the work in accordance to terms stated in the contract. But this regulation did not explain types of default that can be done by the government. The government in Rural Electricity and Free Electricity Installation can one-sidedly terminate the contract and there was no regulation that explicitly describe about payment delays by the government.

\subsection{Compensation in Rural Electricity and Free Electricity Installation Contract}

Compensation is an advantage received by calculating the loss. Related with a breach, compensation is something given toward the party experiencing loss and the amount was usually equal with the loss. Compensation was made to cover for the loss. This is similar to punishment over a crime. With this punishment it was expected that those who breach the contract would never done it again. If there was no compensation, the party who experience the loss was highly at disadvantage and feel that they were unfairly treated. We can determine whether the compensation was quite fair and usually was adjusted to the parties involved. Thus, compensation was given in accordance to the loss.

Jeremy Betham in his book concerning Constitutional Theory suggested that there were 6 types of compensation:

1) Money compensation since money can be use for almost anything. Money was a great compensation for various crimes but the offender did not always able to pay for it.

2) Compensation by itself. This type of compensation was done by giving other goods of equal value with the one being stolen/taken.

3) Compensation concerning testimony

4) Compensation concerning honor

5) Compensation concerning avenges 
6) Compensation by replacing or by sacrificing third party

Compensation should be equal with the crime, because the crime was a terrible event for those experiencing it. It was impossible for a fraud offender to be lightly punished or for a murderer to be released without having to pay for what he/she has done according to the criminal law code. For cases demanding money compensation, it was usually cases against the profit that was expected to be gained by someone. This profit was equal with the loss. Compensation in ethic was due to the consequence of the target. For example, those occur in transaction agreement or labor payment for collective work and others. Related with agreement, it involved at least two parties and commonly creates the rights and duty for all parties.

As commonly known that involvement would create duty for all parties, thus automatically if one accepted this agreement then one should fulfill his duty. If the duty was not done then the agreed condition would not realized and thus create loss for all parties. Rights and duty was like part of the same coin, whereas both were different but inseparable. ${ }^{1}$ Rights for one party were the duty that should be done by the other party. Rights and duty in a contract is part of the contract's substance and formed by interests of all parties involved. Each party would have their own rights and duty according to article 1234 of civil law code.

\subsubsection{Compensation according to civil law code}

According to provisions in article 1234 of civil law code, compensation after breaching a contract should be paid if the debtor was stated negligent in their duty within an agreement, stay negligent or over the deadline determined for the work. This loss should be paid by the debtor after they were stated negligent. According to M. Yahya Harahap, the obligation to compensate did not occur automatically during negligence. This compensation was stated compulsory for the debtor after they were stated negligent or in Dutch called by "in gebrekke stelling" or "in morastelling".

Compensation as stated in article 1234 of civil law code above, consist of three elements such as:

1) The expenditure such as printed cost, official stamp cost, and commercial expense.

2) Loss due to damage such as creditor's loss due to debtor's negligence. For example, spoiled fruits due to delayed delivery, collapsed house due to construction error and thus damaging household furniture.

3) Interest or expected profit such as interest that should be paid in delayed debt payment, loss of profit due to delayed delivery of goods.

In article 1248 of civil law code, it was mentioned that the cause of compensation was the compensation due to "direct" impact of default (breaching contract). In other word, there should be causal relationship between the loss and the breach of contract, or direct effect of debtor's failure to keep their promises. According to Yahya Harahap, it is very difficult to determine the causal relationship of compensation. Constitution itself, in its formulation, has simultaneously revealed about several impact of "one feit". Difficulty occurs in determining causal relationship between the loss and the breach of contract was due to problems within legal domain. According to him, sometimes one event/feit would simultaneously touch two legal domain, criminal and civil law domain. Therefore, the cause of compensation in civil law was only based on the breach of contract.

\subsubsection{Compensation according to presidential regulation for goods/service provision}

There were two things that commonly occur during one involvement which are sanction and compensation event. Since the involvement was engaging at least two (2) parties, sanction event can become compensation for the other party, and vice versa. When provider was given sanction or penalty due to its delayed work, for other party this was considered to be the compensation over loss due to the delayed work. Sanction and compensation can be used to understand the element and criteria within involvement clauses. To make things easier, it can be said that sanction event is anything done toward provider, and compensation event is anything received by user.

Regulation for Government's Goods/Service Provision was based on Presidential Regulation No 54 of 2010 with the latest change by Presidential Regulation No 4 of 2015, about delays was mentioned in two (2) articles such as article 93 and article 120 of Presidential Regulation No 54 of 2010. Article 93 subsection 1 letter a.1 describes that: "PPK was able to one-sidedly terminated the contract if, based on PPK's inspection, goods/service provider did not able to complete all the work after they were given the opportunity up to 50 (fifty) days after the deadline to complete the delayed works"; while letter a.2 suggest that a.2. after given the opportunity to complete the work up to 50 (fifty) days after the deadline of completion if goods/service provider still cannot complete the work.

It is clear that delay was one of the problems mentioned within contract. Delays was determined under PPK's inspection whether goods/service provider would be "capable" in completing the works even after given maximum 50 (fifty) days to complete it. The critical point lies in the assessment of Pejabat Pembuat Komitmen (PPK). This is the importance of PPK to possess adequate competence as the implementer of goods/service provision representing state/regions. Ideal competence requirement was not only concerning the regulation, but also the needs. PPK must control the contract in each stage and they should discover the problems early and not nearly at the end of the contract. In article 120 Presidential Regulation No 54 of 2010 that was replaced with Presidential Regulation No 70 of 2012 mention: "goods/service provider that was delayed in completing the work within the

\footnotetext{
${ }^{1}$ Isnaini, Seberkas Diorama Hukum Kontrak, PT. Revika Petra Media, Surabaya, 2014, pg 15
} 
determined period in the contract due to provider's fault, would be eligible for fine of 1/1000 (one thousandth) of the contract value or partial contract value for each delayed day". In this article, it was provider's fault that causes the delayed works and it was fined during extension period. Maximum extension period as we can see from article 93 was 50 days. There were several types of sanction concerning delays work as regulated by Presidential Regulation No 54 of 2010. There were contract termination clause, fine clause, liquidifying implementation collateral, and blacklist clause. For regional budget, the only reference was Permendagri (Internal Affairs Minister Regulation) 37/2012 concerning Guidance in Composing Regional Budget for Budget year 2013, similar to PMK 25/PMK.5/2011 while solution for regional payment collateral has no legal basis. Therefore, regional policy was necessary if we want to apply payment collateral as one of the solution for delays in provisional contract. Regions should be bold and immediately compose regional regulation tools to anticipate future end-of-the-year delays.

The same thing occurs in the contract for Rural Electricity and Free Electricity Installation which did not propose the clause about compensation directed to "Buyer" or the government. As the carefulness of all parties involved in a contract with their own interests and to gain certain legal protection, contract should be agreed by both parties. If legal action within contractual activities did not have certainty due to negligence, it would bring loss for one of the party. Sanction was also mentioned in the contract clauses if one of the parties breaches the contract. Sanction in government's goods/service provisional contract was commonly known as compensation. This compensation was directed to PPK while fine was directed to provider. Fine is financial sanction directed for the provider because they breach the contract while compensation is financial sanction directed for the PPK due to breach of contract.

For negligence made by PPK in delayed payment to the provider, constitutional regulation mentions that PPK should pay compensation for this delay. How to calculate this delayed payment by PPK in Presidential Regulation No 54 of 2010 with its change in regulation should be adjusted along with Financial Minister Regulation (PMK) No 190/PMK.05/2012 that regulate time norm for publishing Payment Request Letter (SPP) by PPK and directed to Pejabat Penandatanganan Surat Perintah Membayar (PPSPM) also publishing SPM by PPSPM directed to Kantor Pelayanan Perbendaharaan Negara (KPPN), thus there was spare time until payment was received in provider's account. One compensation event that forces PPK to demand the provider to delay their work was national policy. Such as national policy in budget cut for Institutional Ministry in order for savings in Revised Budget. If this savings would cause budget cut for the works under implementation, PPK should delay its implementation and request for DIPA revision and conduct contract adendum adjusted with the available budget. If compensation event was causing compensation, it can only be paid if it can be proved that there were real losses due to compensation event through supporting data and compensation calculation proposed by provider to PPK. Provider did not have the right to receive compensation or to obtain extension time in completing the work if provider was failed or negligent in giving early warning to anticipate or to deal with the impact of compensation event.

\subsection{Obstacles in Government Compensation Payment}

\subsubsection{DIPA (Daftar Isian Pelaksanaan Anggaran) funds was unavailable}

Compensation payment was done by PPK if provider has propose bills along with calculation and the supporting data. The problem would be the unavailable fund within DIPA to pay compensation for the provider. If this occurs, there's a big chance that DIPA would be revised or expecting new fund from APBN-P. In this matter, the accuracy of PPK in escorting and monitoring the contract implementation was highly expected. DIPA is the document for budget implementation that was compiled, implement and hold responsible by Budget User/Budget User Authority. In regional financial management term, DIPA was known as DPA and implemented by regional taskforce. DIPA was composed according to Presidential decree concerning details of central government expenditure budget. DIPA act as the basis for budget implementation after being approved by Minister of Finance. Concerning compensation payment procedure, it was regulated in SSKK. Compensation payment was done by PPK after provider submits a claim along with the calculation and the supporting data. Problem would occur when there was no fund in DIPA to pay for the compensation to the provider. When this occurs, the options were to revise DIPA or wait for new funds from APBN-P. During this period, the accuracy and carefulness of a PPK in escorting and monitoring the contract implementation was highly expected.

\subsubsection{Planned and transparent public budget}

In order to implement the provision of Rural Electricity and Free Electricity Installation, according to Provisional Presidential Regulation No 54 of 2010 and its changes, Rural Electricity and Free Electricity Installation was funded by the government partially through APBN and also local government through APBD. To propose this funding, the government would propose this policy program in the Work Plan for Electricity Provision. Activities in this policy program were coordinated with the local state electricity enterprise (PLN). PLN has the commitment to fulfill the electricity needs for local people that did not have electricity yet.

If we speak about provision, each policy program would always relate with the budget to implement the program. Budget is the tool for planning and monitoring of the program. Formality of a budget would depend on 
the scale of organization. In using this public budget, good planning and monitoring was highly important and it can only gain by the management through learning, analyzing and considering all available possibilities, alternatives and consequences. According to National Committee on Governmental Accounting (NCGA), currently Governmental Accounting Standards Board (GASB), definition of budget was as follow:

" a financial operation plan, which covers the proposed expenditure estimation and the expected revenue source to finance it in certain period of time".

APBN (national revenue and expenditure budget) is the form of state financial management and annually determined according to article 23 of Constitution of Republic of Indonesia 1945 which carried out in open and accountable manner for people's welfare. Therefore, state and local budgets were never unsystematic because they have to go through the working program every year. APBN (national revenue and expenditure budget) and APBD (local revenue and expenditure budget) arrangement was done transparently and not all people could change the program or put new budget subject into RAPBN (national revenue and expenditure budget plan) and RAPBD (local revenue and expenditure budget plan).

\subsection{Balance Principle in Implementation of Compensation in Contractual Relationship}

The valid contract acts as the norm and formed to protect the involved parties within this contractual relationship. Basically, Balance Principle acts so that each transaction would end in fair enrichment, and thus perceived as a fair exchange. This reciprocity is the key concept to create the fairness mentioned above. Munir Fuady differentiates injustice into two types, 1). Procedural injustice means that there was injustice in contract clauses that emerge due to imbalance position of parties involved within the contract; 2). Substantive injustice means that contract clauses was imbalance without relating it to the bargaining process of the contract. Thus compensation is part of a balanced duty/obligation exchange. External legal protection is a fort prepared by constitution regulation to avoid loss and injustice for all parties involved in the contractual relationship (Isnaini, 2014). Balance principle according to Sutan Remy Sjahdeny suggested that balance principle is the positional balance of parties in the contract. Therefore, the government as the subject should fulfill their part in accordance to the agreement, or else the government can be said breaching the contract. However, government acts in its contractual relationship was limited by constitutional regulation particularly those related with state financial budget use. Thus, there should be explicit regulation concerning compensation in clauses and norms, also explicit explanation concerning government's breach of contract that lead to compensation and thus creating legal certainty for the private party to pursue their justice.

\section{Conclusion}

Compensation is part of the unfulfilled obligation and unrealized achievement, and it is valid for both parties. Government would still act as civil law subject and therefore should complete their part (duty) in the contract. There should be effort to force compensation for those breaching the contract because there was expected profit in the contract. However, compensation in government contract was not the same to any common contract. To create certain and balance justice, compensation should not be ignored. With explicit norm for this matter, compensation paid by the government and its procedures, it is expected that the problem of loss in the contract would find a win-win solution because the contract primarily exist to assure certain justice for all parties involved.

\section{References}

Agus Yudha Hernoko, Hukum Perjanjian (Asas Proposionalitas dalam Kontrak Komersial), Jakarta: Kencana, 2014

Bambang Sutiyoso, Reformasi Keadilan dan Pengakkan Hukum di Indonesia, Uji Press, Juli, 2010

Isnaini. (2014). Seberkas Diorama Hukum Kontrak. Surabaya: PT. Revika Petra Media.

Munir Fuady, Hukum Kontrak (Dari Sudut Pandang Hukum Bisnis), PT. Citra Aditya Bakti, Bandung, 2001

Munir Fuady, Konsep Hukum Perdata), PT. Grafindo Persada, Jakarta, 2014

Nomensen Sinamo, Hukum Administrasi Negara, Jala Permata Aksara, Jakarta, 2015

Philipus M. Hadjon, Tatiek Sri Djatmiati, Argumentasi Hukum, Yogyakarta: Gadjah Mada University Press, 2011

Philipus M. Hadjon, Pengantar Hukum Administrasi Indonesia, Yogyakarta: Gadjah Mada University Press, 2011

Sutan Remy Sjahdeny, Aspek Hukum Hubungan Bank dan Perlindungan yang Seimbang bagi Para Pihak (studi mengenai Perjanjian Kredit Bank di Jakarta).(1992). Desertasi. Jakart:Universitas Indonesia, 1992.

Sogar Simamora, Hukum Kontrak (Kontrak Pengadaan Barang dan Jasa Pemerintah di Indonesia), Surabaya: Kantor Hukum "WINS\&Partners", 2013

Burgelijk Wetboek voor Indonesia, Stb,1847-23

Undang-Undang Nomor 18 Tahun 1999 tentang Jasa Kontruksi dan PP No. 29 Tahun 2000 tentang Penyelenggaraan Jasa Kontruksi.

Undang-Undang No 1 tahun 2004 tentang Pembendaharaan Negara

Peraturan Presiden Nomor 54 tahun 2010 tentang Pengadaan Barang/ Jasa 